\title{
FASN Gene
}

National Cancer Institute

\section{Source}

National Cancer Institute. FASN Gene. NCI Thesaurus. Code C26564.

This gene is involved in the production of both lung surfactant and the fatty components

of milk. It also plays a role in the conversion and storage of energy in liver and adipose tissues. 